\title{
FORMAL EDUCATION LEAVES WOMEN FROM THE TRIBUTES OF CHILDHOODS IN SOUTH KALIMANTAN
}

\author{
(Analysis of Demographic and Health Data of Indonesia Year 2012) \\ Norma Yuni Kartika \\ Departement of Geography Education \\ Lambung Mangkurat University, Banjarmasin, Indonesia \\ Email : noerma.unlam@yahoo.com
}

DOI: $10.19184 /$ geosi.v2i1.7393

\begin{abstract}
Article History: Received Date $7^{\text {th }}$ April 2018, Received Revised $27^{\text {th }}$ March 2018, Accepted Date $27^{\text {th }}$ April 2018, Published Date $30^{\text {th }}$ April 2018
\end{abstract}

\begin{abstract}
Education is "upstream" in the development of quality human beings, both provincial scale such as in South Kalimantan and national scale that is Indonesia. Education has a "Downstream" many branches with positive benefits for men and women. For that purpose the formulation of this paper is how the role of formal education in releasing women from child marriage traps in South Kalimantan in 2012. Data Indonesia Demographic and Health Survey (SDKI) Year 2012 became a secondary data source in this study, using the method of analysis secondary data. In accordance with the purpose of this study, this study uses the question module of married women aged 15-49 years in the Province of South Kalimantan 2012. The analysis is done by simple statistics in the form of cross-tabs displayed in the form of tables and bar charts. In order for the discussion to be more comprehensive, analysis is also conducted to find out the independent variable is the level of formal education of women who most contribute in releasing women from the trap of child marriage. The statistic test used is linear logistic regression with the first dummy mating age variable that is the first marriage age under 18 years and above 18 years, using SPSS software aid. Based on the results of the research is known that from the three levels of formal education, formal education at the level of primary education has the greatest contribution seen from the coefficient of determination that women who do not complete the level of primary education or equivalent to junior high education / equal 23.6 percent lead to marriage of children. This means that the higher level of formal education that can be achieved by women in South Kalimantan Province in 2012, the more women are able to escape from the marriage of children.
\end{abstract}

Keywords: formal education, women, traps, child marriage

\section{INTRODUCTION}

Education is "upstream" in the development of quality human beings, both provincial scale such as in South Kalimantan and national scale that is Indonesia. Education has a "Downstream" many branches with positive benefits for men and women. Educational 
support contributes to the first marriage age, and the first marriage age contributes directly to fertility as proposed by Kingsley Davis and Judith Blake. Davis and Blake are prominent demographic sociologists developing a very useful theory for analyzing the determinants of fertility rates in a country or a group of societies embodied in The Social Structure of Family Planning in 1956 (in Davis and Blake, 1982). They say that fertility is influenced by factors called intermediate variables or intermediate variables, one of eleven variables between that is the age of first mating.

In order to achieve the goals in the field of education, the government of Indonesia put it into Law No. 20 of 2003 on National Education System one of which is formal education. Formal education pathway is one of the benchmarks to know the level of education that can be seen from the ownership of the diploma accompanied by the amount of value endorsed by the government, both from the level of primary education, secondary education and higher education. Formal education is used as a reference to assess the high level of one's education. When people are competing to achieve the highest formal education possible, on the other hand there are some people who can not afford formal education appropriately, from the basic level and to the higher levels. Among those who do not have proper education are girls who are trapped in a marriage bond.

Women who are educated, knowledgeable and have an adequate diploma can compete in the job market, educated women have a greater chance of getting a job than those who do not have education at all. Women who work can provide for personal needs and even help meet the needs of household and financially prosperous. Educated women will better maintain their reproductive health, the health of children who are born, and maintain the nutritional needs of children.

The high rate of child marriage in South Kalimantan Province since 2010, 2011, 2012 and 2013 were 17.79 percent, 16.78 percent, 16.06 percent and 15.48 percent, respectively, which ranked first in the marriage cases of children in Indonesia South Kalimantan Province in the emergency status of child marriage. Coalition 18 (Plus) or the Indonesian Coalition to stop child marriage states that the difference in the rules of Law No. 1 of 1974 on Marriage in Indonesia, which allows girls to marry at the age of 16 years and 19-year-old boy encourages child marriage. The definition of child marriage here refers to Law No. 35 of 2014 on child protection and UNICEF which reads: 
"Any marriage carried out below the age of 18 years, before the girl is physically, physiologically, and psychologically ready to shoulder the responsibilities of marriage and childbearing".

There have been many studies that conclude that education is the key to successful men and women, but more visible impact on women not to do early marriage. The Jensen and Thornton (2003) study suggests that early marriage tends to be a significant barrier to women's education. Conversely, improving women's education can contribute to delaying marriage for women. For that purpose the formulation of this paper is how the role of formal education in releasing women from child marriage traps in South Kalimantan.

\section{METHODS}

Indonesia Demographic and Health Survey Data (SDKI) become secondary data source in this research, using secondary data analysis method. The SDKI was conducted periodically by BPS in all provinces in Indonesia in 1991, 1997, 2002/2003, and 2007 and 2012. The objective was to collect data on birth rates, contraceptive prevalence and other information. The module used there are three, namely the household question module, the question module of women ever married aged 15-49 years, and male modules aged 15-49 years, and the question module of adolescents for the SDKI 2007 and 2012. Pursuant to the purpose of this study, then this study uses the question module of women ever married aged 15-49 years in South Kalimantan Province Year 2012.

To see the education of women and the first marriage age (UKP) in South Kalimantan Province, questions were asked from the module of women ever married (1) V106 female education: respondent's education level, and (2) first marriage age V511: age at first cohabitation. The analysis is done by simple statistic in the form of cross table which is displayed in tabular form and bar chart. In order for the discussion to be more comprehensive, the analysis is also conducted to find out the independent variables of the formal education level (primary and secondary education, while the follow-up education can be used in the analysis because it does not meet the statistical test requirements used in the analysis) of women who most contribute in releasing women from child marriage traps in South Kalimantan Province. The statistic test used is linear logistic regression with dummy first mating age variable that is first married age under 18 years and above 18 years old. Statistical test using software assistance is Statistical Package Social Science software (SPSS). 


\section{RESULTS AND DISCUSSION}

1. Results

Education channels in Indonesia consist of fomal education, non formal education, and informal education, all of which can complement and enrich each other. All that is contained in Law no. 20 of 2003 on National Education System. According to the law the definition of education is a conscious and planned effort to create an atmosphere of learning and learning process so that learners are actively developing their own potential, personality, intelligence, noble character, and skills needed by him / her, society, nation and state.

In this study will only analyze formal education in accordance with research objectives. Formal education is a structured and tiered educational path that consists of basic education, secondary education and higher education. Formal education is held in schools in general with systematic, structured, multilevel, tiered activities, from elementary school to university and equals to it. Formal education consists of 3, namely (1) primary education in the form of elementary school (SD) and Madrasah Ibtidaiyah (MI) or other similar forms and Junior High School and Madrasah Tsanawiyah (MTs) or other similar forms; (2) secondary education and in the form of Senior High School, Madrasah Aliyah (MA), Vocational High School (SMK) and Madrasah Aliyah Kejuruan (MAK) or other similar forms; (3) higher education is a secondary education level that includes diploma, undergraduate, master, specialist, and doctoral programs which are held by universities. universities may take the form of academic, polytechnic, high school, institute, or university. The types of education taught in formal education include general, vocational, academic, professional, vocational, religious and special education.

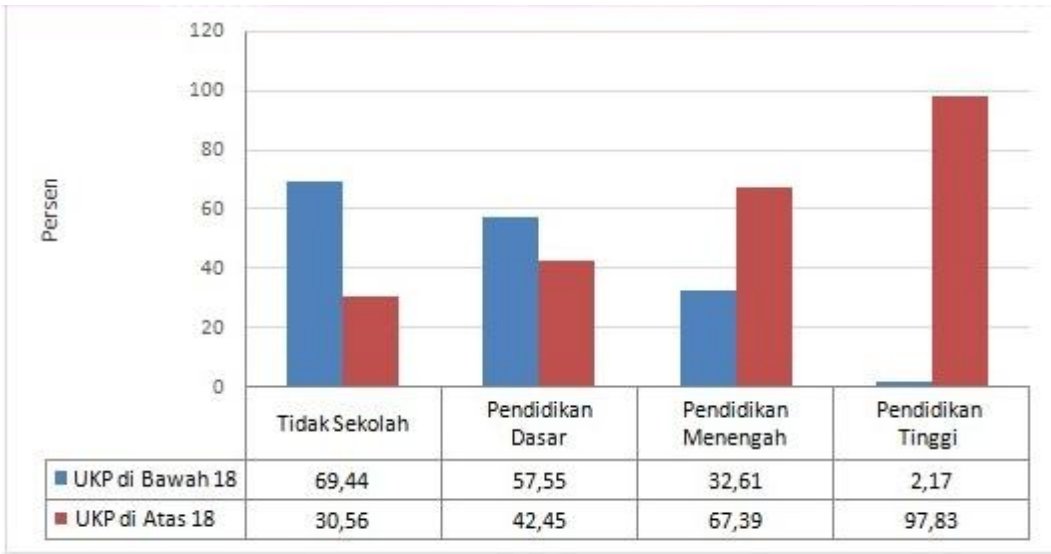

In Figure 1 the 18 year age limit refers to the definition of child under child protection law in Indonesia and the definition of child marriage according to UNICEF. In South 
Kalimantan province macro women aged 15-49 years who never attended school or never finished primary school or equal to 69.44 percent married before the age of 18 years. In line with the results of BPS and UNICEF (2016) research in 2012, 46.7 percent of women who never attended school or never completed primary school married before the age of 18 years. The number has decreased as education outcomes. The 2004 Gupta research results from the International Center for Research of Woman (ICRW) show that education is one of the factors that cause women to marry early.

Meanwhile, when viewed from women in South Kalimantan who married first under 18 years, the higher achievement level of education lower percentage. The percentage decreased with the high achievement level of women's education. This is inversely proportional to women who married first over 18 years, the higher achievement level of education the higher percentage.

The next analysis results are women who do not complete formal education at the level of primary education or equivalent to junior high school education / equivalent 11.7 times at risk of child marriage compared with women who completed basic education equivalent to junior high school / equivalent. The determinant coefficient shows that women who do not have primary education equivalent to junior high school / equivalent 23.6 percent lead to child marriage. The results of this study are similar to the results of all-country studies observed by UNICEF in 2005 that in some countries such as in the Philippines and Tanzania women who did not achieve junior high school education, married under the age of 18 years.

Third, the result of the last analysis is that women who do not complete secondary education or equivalent with high school education or equivalent 3.3 times are at risk of early marriage compared with women who completed high school education or equivalent. Then from the determinant coefficient shows below that women who do not complete high school education or equal 3 percent lead to child marriage. BPS and UNICEF (2016) The sharpest decrease is in senior high school (SMA), when the pretensions dropped to 5 percent, higher education encourages women to marry after the age of 18 years. This is due to increased access and support for girls' education.

\section{Discussions}

From all the results of this study, it can be concluded that formal education at any level of impact on increasing the age of first marriage of women. It is recommended that girls attend formal schooling, the presence of women in formal schooling whether it is in primary school, junior high school, high school and higher education can delay marriage. The 
Government of Indonesia has a compulsory education program. The 6-year compulsory education program, then a 9-year compulsory education program in South Kalimantan Province and Indonesia requires every citizen to obtain primary school (primary) and junior high school (SD) for nine years in a formal school. The program is expected to increase to a 12-year compulsory education program for the entire population to receive secondary or high school (SMA) education. so that people in Indonesia go to school until the age of 18 years. Age where a person is no longer a child category. Better still if women continue to higher education that is college. Estimates if the woman graduated from the degree program or the deed IV age of approximately 22 years, the age includes the age of adulthood, because a person is said to be an adult if it is even 21 years in accordance with Article 6 paragraph (2) Law No. 1 Year 1974 about marriage. Age where a person may marry without the consent of both parents. Malhotra (1997) the importance of school attendance, relevant to life transitions such as marriage.

Of the three levels of formal education, formal education at the level of primary education or equivalent to junior high school education / equivalent has the greatest contribution seen from the coefficient of determination. Because schools are a medium of socialization, socialization is a lifelong process of social learning. The process of socialization occurs in groups or social institutions that play an important role in the lives of children are family, peers, school and others. Sociologically, education is a process of socialization that is in institutions with institutions in the form of schools. School is the second educational institution after a formal family, which has an important role in the process of socialization of children in changing social behavior. An analysis of education status and marital status by BPS and UNICEF (2016) indicates a relationship between lower educational attainment levels and marriage of child age, whereas higher levels of educational attainment will encourage postponement of marriage to adulthood.

It requires appropriate government policies and programs to attract women to formal schooling. The advantages of formal education other than when graduated have a diploma, social interaction is honed well, interaction with teachers and interaction with fellow students. As Singh and Samara (1996) noted that formal schools form ideas and values, which have the effect of knowledge. Where once reproductive health education was taboo, it is now one of the compulsory subjects in formal schooling. In order for students to know such as reproductive health, maintaining good reproductive health, ideal first marriage age and the risk of child marriage. So that the marriage of children through education can be broken so as not to continue in the next generation. 
The benefits of formal education in addition to releasing women from child marriage traps in South Kalimantan Province, formal education certificates became tickets for women competing in the job market, the chances of getting a decent job high. Working women will have income so that it has economic independence and can help the family economy. As the theory of economic independence in the Marshan (2011) study shows that as women are educated and have income, in marriage women will be less economically dependent and women with greater economic independence will delay marriage.

Education is one of the 17 global Goals of Sustainable Development Goals (SDGs), the 4th global goal of quality education to be achieved by 2030. Quality education by ensuring equitable distribution of education and enhancing learning opportunities for all, ensuring inclusive education and fair and encouraging lifelong learning opportunities for everyone.

\section{CONCLUSION}

The role of education, especially formal education, led to the presence of women in the formal school environment. Formal education at every level, be it primary education, secondary education and higher education affects the increasing age of first marriage of women. The formal attainment achieved by women, the higher the level of achievement contributes to the release of women from the trap of child marriage in South Kalimantan. Through proper planning the social problems that will arise can be addressed properly. One of the social issues concerning education for women trapped in child marriages that lead to dropping out or not continuing to higher education levels as well as unmarried women of any age but lacking a formal education diploma as envisaged can be overcome by education nonformal as an alternative solution. By joining package A, package B program, or other equivalent form in the non-formal education path. The role of schools to socialize and realize the importance of education, especially for girls to know what rights are owned as children and women. Thus, Indonesia in general and South Kalimantan in particular will have a strong generation if it has an educated and knowledgeable mother.

\section{REFERENCES}

Badan Pusat Statistik. 2011. Statistik Kesejahteraan Rakyat Tahun 2010. Banjarmasin : BPS Badan Pusat Statistik. 2011. Statistik Kesejahteraan Rakyat Tahun 2011. Banjarmasin : BPS Badan Pusat Statistik. 2011. Statistik Kesejahteraan Rakyat Tahun 2012. Banjarmasin : BPS 
Badan Pusat Statistik. 2011. Statistik Kesejahteraan Rakyat Tahun 2013. Banjarmasin : BPS

Badan Pusat Statistik, Badan Kependudukan dan Keluarga Berencana Nasional dan Kementerian Kesehatan. 2013. Survei Demografi dan Kesehatan Indonesia 2012. Indonesia : BPS

Badan Pusat Statistik dan UNICEF. 2016. Kamajuan Yang Tertunda : Analisis Data Perkawinan Usia Anak di Indonesia. Jakarta : BPS

Choe, M.K, Shyam Thapa and Sulistinah Irawati Achmad. 2001. Early Marriage and Chidbearing in Indonesia and Nepal. East-West Center Working Papers. Population Series, No.108-15.

Davis, Kingsley dan Blake, Judith. 1982. Struktur Sosial dan fertilitas : Suatu Kerangka Analitis. Kependudukan : Liku-Liku Penurunan Kelahiran. Ed Singarimbun. Yogyakarta : LP3ES Bekerjasama Degan lembaga Kependudukan UGM

Gupta, Geeta Rao. 2004. Child Marriages: Social and Economics Linkages and Opportunities For Intervention. ICRW

Jensen, Robert and Rebecca Thornton. 2003. Early Female Marriage in the Developing World. Gender and Development, Vol. 11, No. 2 Marriage (Jul., 2003), pp. 9-19

Malhotra, A. 1991. Gender and The Minning of Marriage : Rural-Urban Differences in Java. Journal Marriage and Family. Volume 59, Nomor 2, Halaman 434-450.

Marshan. Joseph Natanael, M. Fajar Rakhmadi dan Mayang Rizky. 2011. Prevalence of Chil Marriage and Its Determinants among Young Women in Indonesia. The SMERU Research Institute. UNICEF-Bappenas-SMERU

Singh, Susheela dan Renee Samara. 1996. Early Marriage Among Woman In Developing Countries. International Family Planning Perspectives, 22: 148-157 dan 175.

UNICEF. 2005. Early Marriage A Harmful Traditional Practice. The United Nations Children's Fund (UNICEF).

Undang-Undang Dasar Negara Republik Indonesia Tahun 1945

Undang-Undang Republik Indonesia Nomor 1 Tahun 1974 Tentang Perkawinan dan Kompilasi Hukum Islam. Bandung: Citra Umbara

Undang-Undang Republik Indonesia Nomor 20 Tahun 2003 Tentang Sistem Pendidikan Nasional.

Undang-Undang Republik Indonesia Nomor 35 Tahun 2014 Tentang Perlindungan Anak 